\title{
Alienimonas chondri sp. nov., a novel planctomycete isolated from the biofilm of the red alga Chondrus crispus
}

\author{
Inês Vitorino ${ }^{\mathrm{a}, \mathrm{b}}$, Luciana Albuquerque ${ }^{\mathrm{c}}$, Sandra Wiegand ${ }^{\mathrm{d}}$, Nicolai Kallscheuer ${ }^{\mathrm{d}}$, \\ Milton S. da Costa $^{\mathrm{e}}$, Alexandre Lobo-da-Cunha ${ }^{\mathrm{b}, \mathrm{f}}$, Christian Jogler ${ }^{\mathrm{g}}$, Olga Maria Lage ${ }^{\mathrm{a}, \mathrm{b}, *}$ \\ a Departamento de Biologia, Faculdade de Ciências, Universidade do Porto, Rua do Campo Alegre s/no., 4169-007 Porto, Portugal \\ b CIMAR/CIIMAR, Centro Interdisciplinar de Investigação Marinha e Ambiental, Universidade do Porto, Terminal de Cruzeiros do Porto de Leixões, Avenida \\ General Norton de Matos, S/N, 4450-208 Matosinhos, Portugal \\ ${ }^{\mathrm{c}}$ Centro de Neurociências e Biologia Celular, Universidade de Coimbra, 3004-517 Coimbra, Portugal \\ d Department of Microbiology, Radboud University, Heyendaalseweg 135, Nijmegen, The Netherlands \\ e Departamento de Ciências da Vida, Apartado 3046, Universidade de Coimbra, 3001-401 Coimbra, Portugal \\ f Laboratório de Biologia Celular, Instituto de Ciências Biomédicas Abel Salazar, ICBAS, Universidade do Porto, Rua de Jorge Viterbo Ferreira, 228, 4050-313 \\ Porto, Portugal \\ ${ }^{\mathrm{g}}$ Institute of Microbiology, Department of Microbial Interactions, Friedrich-Schiller University Jena, Philosophenweg 12, Jena, Germany
}

\section{A R T I C L E I N F O}

\section{Article history:}

Received 14 January 2020

Received in revised form 27 March 2020

Accepted 1 April 2020

\section{Keywords:}

Planctomycetes

Novel taxa

Macroalgae

Biofilm

Cell division

Apical and lateral budding

\begin{abstract}
A B S T R A C T
The phylum Planctomycetes comprises bacteria with peculiar and very unique characteristics among prokaryotes. In marine environments, macroalgae biofilms are well known for harboring planctomycetal diversity. Here, we describe a novel isolate obtained from the biofilm of the red alga Chondrus crispus collected at a rocky beach in Porto, Portugal. The novel strain $\mathrm{LzC}^{\mathrm{T}}$ is motile, rosette-forming with spherical- to ovoid-shaped cells. $\mathrm{LzC}^{\mathrm{T}}$ forms magenta- to pinkish-colored colonies in M13 and M14 media. Transmission and scanning electron microscopy observations showed a division by polar and lateral budding. Mother cells are connected to the daughter cells by a tubular neck-like structure. The strain requires salt for growth. Vitamins are not required for growth. Optimal growth occurs from 15 to $30^{\circ} \mathrm{C}$ and within a pH range from 5.5 to 10.0 . Major fatty acids are anteiso-C15:0 (54.2\%) and iso-C15:0 (19.5\%). Phosphatidylglycerol, diphosphatidylglycerol and an unidentified glycolipid represent the main lipids and menaquinone 6 (MK-6) is the only quinone present. $16 \mathrm{~S}$ rRNA gene-based phylogenetic analysis supports the affiliation to the phylum Planctomycetes and family Planctomycetaceae, with Alienimonas as the closest relative. Strain $\mathrm{LzC}^{\mathrm{T}}$ shares $97 \%$ 16S rRNA gene sequence similarity with Alienimonas californiensis. $\mathrm{LzC}^{\mathrm{T}}$ has a genome size of $5.3 \mathrm{Mb}$ and a $\mathrm{G}+\mathrm{C}$ content of $68.3 \%$. Genotypic and phenotypic comparison with the closest relatives strongly suggest that $\mathrm{LzC}^{\mathrm{T}}\left(=\mathrm{CECT} 30038^{\mathrm{T}}=\mathrm{LMG} \mathrm{XXXT}\right)$ is a new species of the genus Alienimonas, for which we propose the name Alienimonas chondri sp. nov., represented by $\mathrm{LzC}^{\mathrm{T}}$ as type strain.

16S rRNA gene accession number: GenBank= MN757873.1.

Genome accession number: GenBank=WTPX00000000.
\end{abstract}

(c) 2020 Elsevier GmbH. All rights reserved.

\section{Introduction}

The phylum Planctomycetes, an underexplored group of bacteria, possess unique features which keep challenging the scientific community [52,53]. This phylum is classified within the Planctomycetes-Chlamydiae-Verrucomicrobia (PVC) superphylum

\footnotetext{
* Corresponding author at: Departamento de Biologia, Faculdade de Ciências, Universidade do Porto, Rua do Campo Alegre s/no., 4169-007 Porto, Portugal.

E-mail address: olga.lage@fc.up.pt (O.M. Lage).
}

[51]. Although an extensive shift in planctomycetal research is currently taking place, these organisms still remain a mystery, mainly due to their peculiar cell division mechanism that does not rely on the otherwise universal bacterial division protein FtsZ [52,53]. While prokaryotes usually divide by binary fission, many of the cultured Planctomycetes are reported to reproduce by budding with the exception of members of the classes Phycisphaerae and Cand. Brocadiae (anammox-performing planctomycetes) [35,52]. Moreover, variations of the budding process were recently described, such as lateral budding [52], which unveiled novel models of cell division. Planctomycetes possess a complex system of cytoplas- 
matic membrane invaginations that were originally misinterpreted as structures resembling a eukaryotic nucleus. These membrane invaginations also account for an unusually enlarged periplasmic space $[4,34]$.

Recent planctomycetal genome analyses revealed particular features. They display large genomes with an average genome size of $7.6 \mathrm{Mb}$, with members of the family Gemmataceae having the largest genome sizes of up to $12.4 \mathrm{Mb}[35,52,53]$. The $\mathrm{G}+\mathrm{C}$ content of planctomycetal genomes differs significantly between species. Most planctomycetal genomes were also found to possess a large number of proteins with unknown function (40-50\% of all annotated genes) [52,53]. Giant genes (with a size of up to $49 \mathrm{~kb}$ ) have also been detected in planctomycetal genomes, but are most often of unknown function $[20,27,28,52]$. Planctomycetes are emerging as biotechnologically relevant bacteria, as already demonstrated in antimicrobial and anti-cancer studies [12,21,24]. The planctomycetes share common characteristics with known producers of bioactive metabolites, like Actinobacteria, namely large genomes and complex life cycles. Furthermore, they possess genes encoding multi-domain protein complexes, e.g. polyketide synthases (PKS) and non-ribosomal peptide synthases (NRPS), that are known to be involved in the production of two large classes of bioactive small molecules (also referred to as secondary metabolites) [18,21,23]. While found in most habitats on earth, only a low percentage of the diversity known from molecular environmental studies is covered by axenic cultures [35,53]. In marine environments, macroalgal biofilms harbor a great range of planctomycetal diversity [2]. In particular, five novel species and three genera were isolated from macroalgae of the Portuguese coast $[8,10,32]$, all belonging to the 'Pirellula clade' (now referred to as family Pirellulaceae) [17]. As the diversity of the described planctomycetes is still at an early stage, isolation and characterization of novel taxa is important to enlarge the knowledge on planctomycetal taxonomy, cell biology, ecology and evolution. This endeavor was brought forward by a recent study unveiling unique aspects of the biology of planctomycetes [52]. One of the many novel species was Alienimonas californiensis, recently described as a novel genus [5].

In this study, we focus on the biofilm of the red macroalga Chondrus crispus for the isolation of novel planctomycetes. One isolate, designated $\mathrm{LzC}_{2} \mathrm{~T}$, was chosen for further characterization and its genome was sequenced. Here, we show that this isolate is a novel species belonging to the genus Alienimonas with the sole species Alienimonas californiensis as its closest relative. We propose the name Alienimonas chondri sp. nov., represented by $\mathrm{LzC}^{\mathrm{T}}$ as the type strain.

\section{Material and methods}

Isolation and ecology

Strain $\mathrm{LzC}^{\mathrm{T}}$ was isolated from the red macroalga Chondrus crispus. This alga was sampled on the rocky beach of Praia da Luz in Porto (Portugal) $\left(41^{\circ} 09^{\prime} 12.38 \mathrm{~N}, 8^{\circ} 40^{\prime} 45.91 \mathrm{~W}\right)$. The alga was collected in October 2018 during a low tide and brought to the laboratory in a cold chamber. The seawater temperature was $10^{\circ} \mathrm{C}$. Pieces of the alga (about $1.5 \times 1.5 \mathrm{~cm}$ ) were washed in natural sterilized seawater to remove non-attached bacteria. To prevent fungal contamination, a subsequent washing step for $30 \mathrm{~min}$ was performed in seawater containing $1 \%(\mathrm{w} / \mathrm{v})$ of the antifungal agent econazole nitrate (Pevaryl ${ }^{\circledR}$ ). The biofilm on the algal surface was then scraped off and the obtained biological material was resuspended in sterile natural seawater. $50 \mu \mathrm{L}$ of the mixture were inoculated in M13 medium plates [33], previously sprayed with Pevaryl ${ }^{\circledR}$ for one month. Isolated colonies were re-inoculated in new medium. Cultures of the isolated strain $\mathrm{LzC}_{2}^{\mathrm{T}}$ were then main- tained in M13 medium or M14 medium [33] at $25^{\circ} \mathrm{C}$ and preserved in medium M13 supplemented with $20 \%(\mathrm{v} / \mathrm{v})$ glycerol at $-80^{\circ} \mathrm{C}$.

\section{Phylogenetic inference}

Genomic DNA of strain $\mathrm{LzC}^{\mathrm{T}}$ was extracted using the E.Z.N.A. Bacterial DNA Isolation Kit (Omega). For the identification of the isolate, the 16S rRNA gene was amplified with the primers $27 \mathrm{~F}$ and $1492 \mathrm{R}$ and the PCR was performed as previously described by Bondoso and collaborators [9]. PCR products obtained were purified using the GFX ${ }^{\mathrm{TM}}$ PCR DNA and Gel Band Purification Kit (Amersham Biosciences). Sequencing was performed at GATC Biotech $^{\mathrm{TM}}$. Sequence analyses were carried out using Geneious R11 (Biomatters Ltd, Auckland, New Zealand). 16S rRNA gene-based phylogeny was computed for strain $\mathrm{LzC}^{\mathrm{T}}$ (GenBank accession number MN757873.1) and the type strains of related described planctomycetal species. 16S rRNA gene sequences were aligned with SINA [42]. The phylogenetic analysis was done employing a maximum likelihood approach with 1000 bootstraps, the nucleotide substitution model GTR, gamma substitution and estimation of proportion of invariable sites (GTRGAMMAI option) [49]. Three 16S rRNA genes of bacterial strains from the PVC superphylum served as outgroup. The average nucleotide identity (ANI) was calculated using OrthoANI [37] and the average amino acid identity (AAI) was obtained using the aai.rb script of the enveomics collection [44]. The percentage of conserved proteins (POCP) was calculated as described [43]. The $r p o B$ gene sequences were taken from publicly available genome annotations and sequence identities were determined as previously described [11]. The alignment and matrix calculation were performed upon extracting only those parts of the sequence that would have been sequenced with the described primer set and the alignment and matrix calculation was done with Clustal Omega [48].

\section{Genome sequencing and analysis}

A paired-end sequencing library was prepared with the Nextera XT DNA Library Preparation Kit (Illumina, San Diego, USA) according to the manufacturer's instructions and were sequenced on an Illumina MiSeq System employing 600 cycles with a MiSeq Reagent Kit v3 (Illumina). Adapter clipping and read trimming was done with Trimmomatic v0.35 [7]. After adapter removal, FastQ Screen v0.4.4 [54] was employed to filter the data set for contaminations and reads of low complexity were discarded with PRINSEQ lite v0.20.4 [46]. Subsequently, overlapping paired-end reads were merged using FLASH v1.2.11 [39]. The genome was assembled with SPAdes v3.7.0 [1]. Scaffolding of pre-assembled contigs based on the reuse of the paired-end library by using SSPACE [6] was performed. The genome assembly was examined by CheckM [41] and QUAST [22]. Finally, genome annotation was performed with Prokka v1.12 [47]. The genome was submitted to NCBI GenBank and is available under accession number WTPX00000000. The search for giant proteins was manually curated. The primary metabolism was analyzed by examining locally computed InterProScan [40] results cross-referenced with information from the UniProt database [50] and BLASTp results of 'typical' protein sequences. The program dbCAN2 [56], which automatically mines the CAZy [38] database, was used to determine the numbers of putative carbohydrate active enzymes. The genome of the strain was also analyzed for the presence of secondary metabolite biosynthetic gene clusters using the platform antiSMASH 5.0 [3]. Whole genome-based multilocus sequence analysis (MLSA) for complementary phylogenetic interference was determined with proteinortho5 [36] with the 'selfblast' option enabled. Alignment of protein sequences of the resulting orthologous groups was performed using MUSCLE v.3.8.31 [19]. After clipping, filtration 


\section{A) 16S rRNA gene}

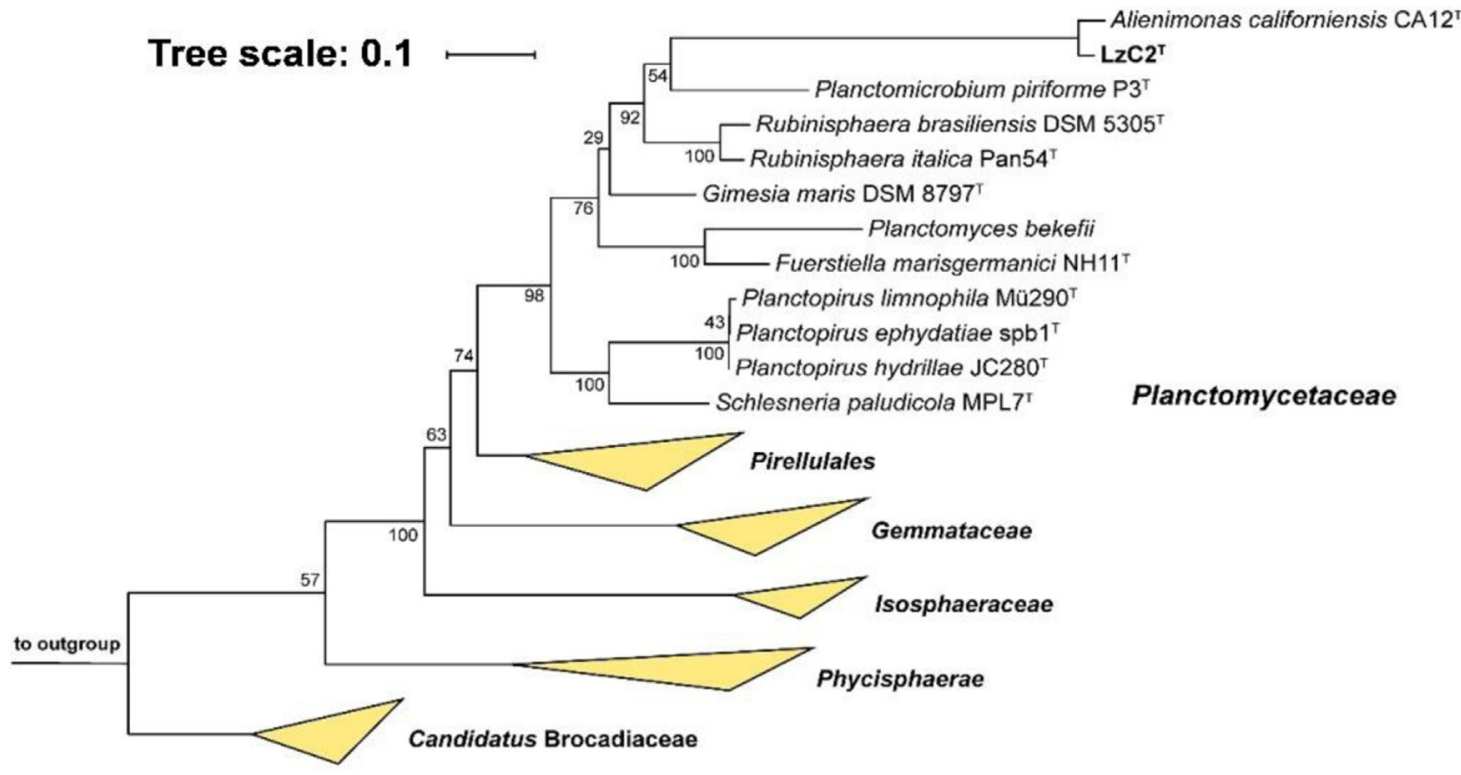

B) MLSA

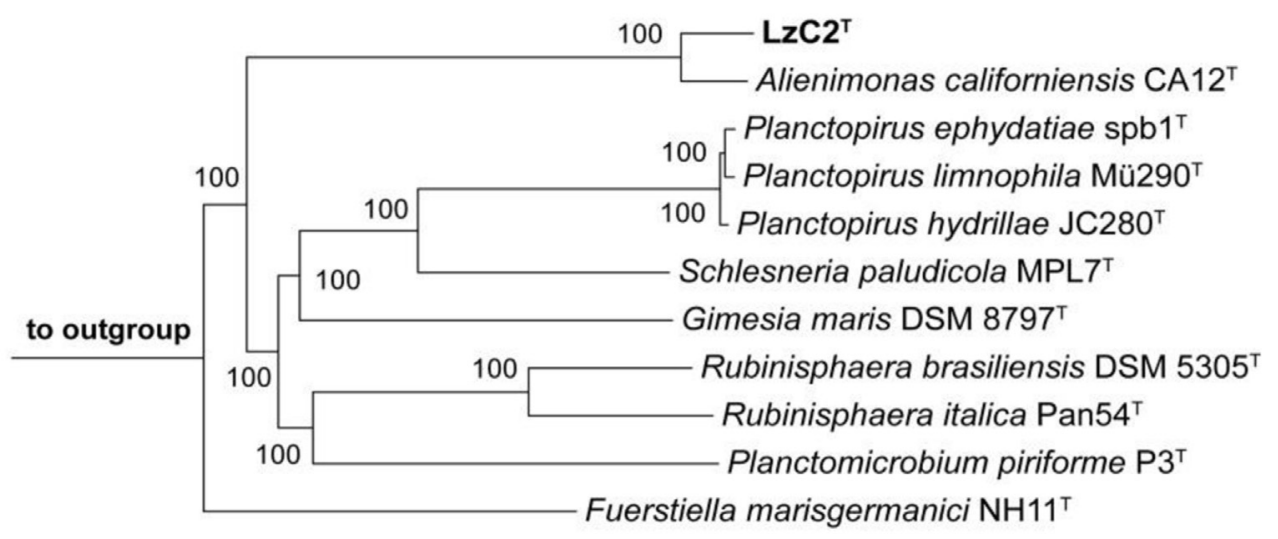

Tree scale: $0.1 \longmapsto$

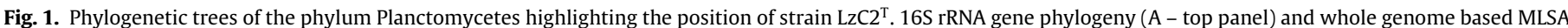

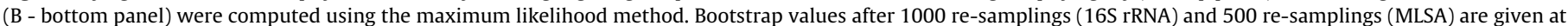
the nodes. The outgroup consists of three non-planctomycetes PVC superphylum members.

of the partially aligned $\mathrm{C}$ - and $\mathrm{N}$-terminal regions and poorly aligned internal regions was performed by Gblocks [13]. The final alignment was concatenated and clustered using the maximum likelihood method implemented by RaxML [49] with the "rapid bootstrap" method and 500 bootstrap replicates. Concatenated gene sets strains from the Phycisphaera and Candidatus Brocadiaceae served as outgroup.

\section{Microscopy}

Morphological characterization of strain $\mathrm{LzC}^{\mathrm{T}}$ was carried out by phase contrast, scanning electron microscopy (SEM) and transmission electron microscopy (TEM) during the exponential phase of growth in M14 medium. Photographic records of colonies of the strain in M14 medium were also obtained. For phase contrast microscopy, cells were observed in a Nikon Eclipse Ci equipment under 1000x magnification. For SEM, cells were fixed in $2.5 \%$ $(\mathrm{v} / \mathrm{v})$ glutaraldehyde in marine buffer, $\mathrm{pH} 7.0$ for $2.5 \mathrm{~h}$, dehydrated through a graded ethanol series, critical point-dried and observed with a HITACHI S-570 microscope. For TEM, cells were fixed in 2.5\% $(\mathrm{v} / \mathrm{v})$ glutaraldehyde in marine buffer $(\mathrm{pH} 7.2)$ for $2 \mathrm{~h}$ and post-fixed in $1 \%(\mathrm{v} / \mathrm{v})$ osmium tetroxide in the same buffer for $4 \mathrm{~h}$ followed by $1 \%(\mathrm{v} / \mathrm{v})$ uranyl acetate for $1 \mathrm{~h}$. Cells were dehydrated through a graded ethanol series, followed by propylene oxide treatment and were ultimately embedded in Epon resin. Ultrathin sections were stained for $10 \mathrm{~min}$ in $1 \%(\mathrm{v} / \mathrm{v})$ uranyl acetate and for $10 \mathrm{~min}$ in Reynolds lead citrate. The sections were examined using a 100CXII transmission electron microscope (JEOL).

\section{Physiology and chemotaxonomy}

Unless otherwise stated, all physiological tests were performed at $25^{\circ} \mathrm{C}$ using $\mathrm{M} 13$ medium. In liquid medium used for $\mathrm{NaCl}$ tolerance and $\mathrm{pH}$ range the results were recorded after seven days 


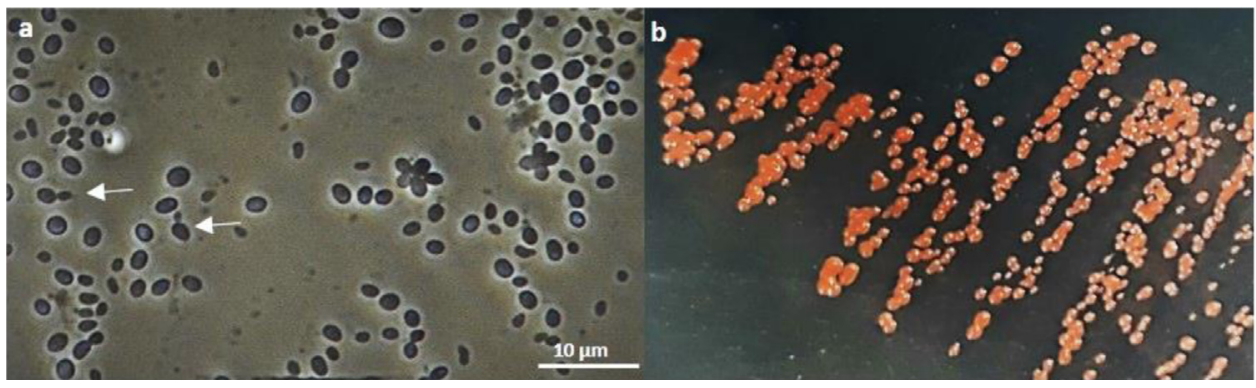

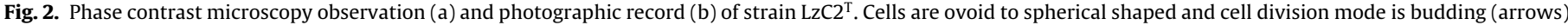
(a). Colonies of this strain appear circular and pink colored in M14 medium (b).

by measuring of the optical density at $600 \mathrm{~nm}\left(\mathrm{OD}_{600}\right)$. The results of an analysis of vitamin requirements and growth temperature range were determined visually after cultivation for seven days on solid medium. $\mathrm{NaCl}$ tolerance was evaluated in duplicate in Falcon tubes by using artificial seawater (ASW) medium with added salt concentrations of $0 \%, 1 \%, 2 \%, 3 \%, 3.5 \%, 5 \%, 6 \%, 7 \%$ and $10 \%$ (each $\mathrm{w} / \mathrm{v}$ ). The $\mathrm{pH}$ range for growth was evaluated in 96 -well plates in triplicate with M13 buffered with $10 \mathrm{mM}$ of each of the following buffers: MES for $\mathrm{pH}$ 5.5, 6.0 and 6.5, Tris-HCl for $\mathrm{pH} 7.5$ and CHES for $\mathrm{pH}$ 8.0, 8.5, 9.0 and 10.0. For analyzing vitamin requirements, M13 medium was prepared with and without a vitamin supplement. Temperature for growth was assessed in M13 medium at 5, 15, 20, $25,30,37$ and $40^{\circ} \mathrm{C}$. Catalase test was performed by placing a drop of hydrogen peroxide on a microscope slide with a $\mathrm{LzC}^{\mathrm{T}}$ colony. Bubble formation indicated the presence of catalase. For chemotaxonomic analyses of respiratory quinones, polar lipids and fatty acids strain $\mathrm{LzC}^{\mathrm{T}}$ was cultured for 15 days; biomass was collected and lyophilized. The biomass was processed according to the protocols described previously [14-16]. Anaerobic growth was tested in anaerobic chambers (GENbox Anaer; BioMérieux) according to the manufactures and results were recorded after one week.

\section{Results and discussion}

Sequences obtained from the analysis of the 16S rRNA gene established the affiliation of strain $\mathrm{LzC}^{\mathrm{T}}$ to the family Planctomycetaceae. In the phylogenetic tree, $\mathrm{LzC}^{\mathrm{T}}$ clustered monophyletically with the recently described strain Alienimonas californiensis $\mathrm{CA} 12^{\mathrm{T}}$ (Fig. 1A). Strain $\mathrm{LzC}^{\mathrm{T}}$ shares a $16 \mathrm{~S}$ rRNA gene sequence identity of $97.0 \%$ with $A$. californiensis. This value is below the proposed species threshold of $98.7 \%$ [55], but above the genus threshold of 94.5\% [55], indicating that $\mathrm{LzC}^{\mathrm{T}}$ belongs to the genus Alienimonas, but is not a strain of the species A. californiensis. The computed MLSA phylogenetic tree supports this relation (Fig. 1B). A partial sequence of the RNA polymerase subunit beta gene $(r p o B)$ is commonly applied as molecular phylogenetic marker in the order Planctomycetales [11]. Strain $\mathrm{LzC}^{\mathrm{T}}$ shares $92.9 \%$ rpoB similarity with A. californiensis $\mathrm{CA} 12^{\mathrm{T}}$. This value is below the proposed species threshold of 96.3\% [11], but above the genus threshold of 75.5-78\% [25], thus confirming the results of the $16 \mathrm{~S}$ rRNA gene comparison. Other phylogenetic markers, such as ANI [26], AAI [29] and POCP [39] were also applied to enhance the accuracy in the determination of phylogenetic affiliation. Percentages of similarity between $\mathrm{LzC}^{\mathrm{T}}$ and CA $12^{\mathrm{T}}$ were $79.5 \%, 78.7 \%$ and $79.7 \%$, for ANI, AAI and POCP, respectively, which is in agreement with $\mathrm{LzC}^{\mathrm{T}}$ being placed as a novel species of the genus Alienimonas.

Genomic features (genome with 355 scaffolds) of $\mathrm{LzC}^{\mathrm{T}}$ in comparison to A. californiensis $\mathrm{CA} 12^{\mathrm{T}}$ genome are summarized in Table $1 . \mathrm{LzC}^{\mathrm{T}}$ has a genome size of $5.3 \mathrm{Mb}$ and a $\mathrm{G}+\mathrm{C}$ content of $68.3 \%$. Other type strains of the family have a $\mathrm{G}+\mathrm{C}$ content below $60.0 \%$ [52]. An interesting feature of most planctomycetal genomes
Table 1

Genomic features of $\mathrm{LzC} 2^{\mathrm{T}}$ compared with its closest relative A. californiensis $\mathrm{CA} 12^{\mathrm{T}}$ (retrieved from ${ }^{1}$ Boersma et al. [5]).

\begin{tabular}{|c|c|c|}
\hline Characteristics & $\mathrm{LzC}^{\mathrm{T}}$ & ${ }^{1}$ A. californiensis $\mathrm{CA} 12^{\mathrm{T}}$ \\
\hline Genome size (Mbp) & 5.3 & 5.4 \\
\hline DNA G+C content $(\%)$ & 68.3 & 70.7 \\
\hline $\begin{array}{l}\text { 16S rRNA gene sequence } \\
\text { similarity to strain } \mathrm{LzC}^{\mathrm{T}}(\%)\end{array}$ & - & 97.0 \\
\hline Completeness (\%) & 94.8 & 94.8 \\
\hline Contamination (\%) & 0 & 0 \\
\hline Number of predicted genes & 4345 & 4382 \\
\hline $\begin{array}{l}\text { Number of protein-coding } \\
\text { genes }\end{array}$ & 4232 & 4309 \\
\hline Coding density (\%) & 89.2 & 88.5 \\
\hline $\begin{array}{l}\text { Number of hypothetical } \\
\text { proteins }\end{array}$ & 2310 & 1798 \\
\hline Hypothetical proteins (\%) & 54.6 & 41.7 \\
\hline Number of tRNA genes & 57 & 65 \\
\hline
\end{tabular}

is the considerably high number of genes with unknown function. The genome of $\mathrm{LzC}^{\mathrm{T}}$ is not an exception since more than $50 \%$ of the predicted proteins are annotated as hypothetical or uncharacterized proteins (Table 1). Extremely large genes (with a size of up to $49 \mathrm{~kb}$ ) have been detected in some planctomycetal genomes [20], mostly encoding proteins with unknown function. The genome of our novel isolate harbors a single giant gene (with a size of $25 \mathrm{~kb}$ ) related to a bifunctional hemolysin/adenylate cyclase-encoding gene. The presence of primary metabolic pathways involved in the catabolism of sugars (Embden-Meyerhof-Parnas pathway, gluconeogenesis, pentose phosphate pathway, tricarboxylic acid cycle and Entner-Doudoroff pathway) were also analyzed based on enzymes participating in these pathways encoded in the $\mathrm{LzC}^{\mathrm{T}}$ genome. Indeed, genes were found for all pathways, except for gluconeogenesis, for which only a partial set of genes coding for respective enzymes of this pathway could be identified. Genes coding for enzymes of the glyoxylate shunt, which is typically required for anaplerosis during growth with acetate or fatty acids as sole carbon and energy source, were not found. Data of $A$. californiensis $\mathrm{CA} 12^{\mathrm{T}}$ was used for comparison (Supplementary Table 1 ). Presence of genes encoding carbohydrate-degrading enzymes was also analyzed in the $\mathrm{LzC} 2^{\mathrm{T}}$ genome, as well as data of $A$. californiensis $\mathrm{CA} 12^{\mathrm{T}}$ for comparison (Table 2 ). The carbohydrate-degrading enzyme profile of $\mathrm{LzC} 2{ }^{\mathrm{T}}$ was similar to the profile of strain $\mathrm{CA} 12^{\mathrm{T}}$. As mentioned previously, planctomycetes are also emerging as biotechnologically important bacteria. Using the antiSMASH platform, the $\mathrm{LzC}^{\mathrm{T}}$ genome was analyzed for the presence of biosynthetic gene clusters and five putative clusters were detected: three of these appear to be related to the synthesis of terpenes (likely including the pigmenting carotenoids), one encodes a type III PKS and one cluster was unclassified.

A summary of some of the analyzed features of strain $\mathrm{LzC}^{\mathrm{T}}$ is shown in Table 3, as well as data of A. californiensis $\mathrm{CA}_{12}^{\mathrm{T}}$ for comparison. Morphologically, $\mathrm{LzC}^{\mathrm{T}}$ cells are ovoid to spherical, with 


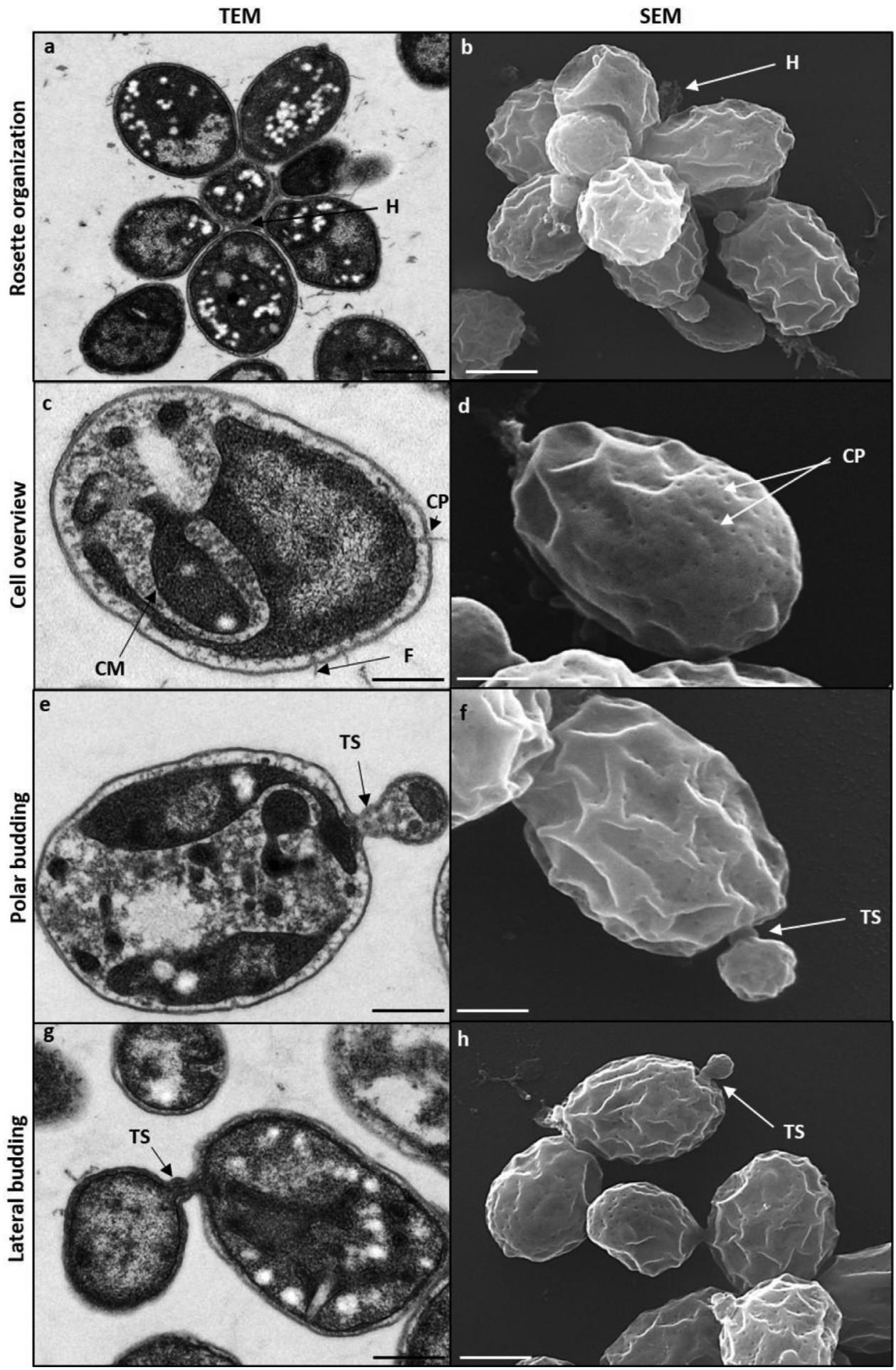

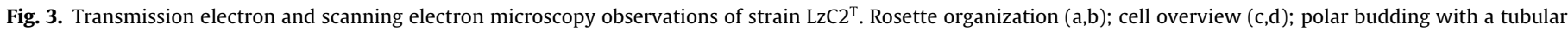

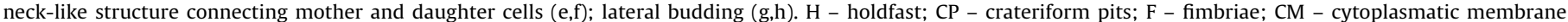
invaginations; TS - tubular shaped structure. Bars - $500 \mathrm{~nm}(\mathrm{a}, \mathrm{h})$ and $200 \mathrm{~nm}(\mathrm{c}-\mathrm{g})$.

sizes of $1.4 \pm 0.3 \times 1.0 \pm 0.2 \mu \mathrm{m}$, while colonies appeared circular and pink-colored in both agar M13 and M14 media (Fig. 2). Motility of the cells was confirmed using phase contrast microscopy. SEM and TEM observations showed the characteristic rosette organization of planctomycetes, in which cells aggregate through their holdfast structures (Fig. 3a and b) . Crateriform pits, commonly found in planctomycetes, are also easily observed to be distributed uniformly on the cell surface (Fig. $3 c$ and d). Ultrathin sections of
$\mathrm{LzC}^{\mathrm{T}}$ showed an overall typical cell plan of planctomycetes with a large periplasm, invagination of the cytoplasmic membrane, cytoplasm with ribosomes, permanently condensed DNA and storage material (Fig. 3a, c, e and g). Crateriform pits were often associated with fimbriae (Fig. 3c). Reproduction by budding (a conserved feature of members of the class Planctomycetia [35,52,53] occurs through an apical or a lateral tubular neck-like structure connecting the mother and daughter cells (Figs. $1 \mathrm{a}, \mathrm{b}$ and $3 \mathrm{e}-\mathrm{h}$ ). A very sim- 
Table 2

Carbohydrate-degrading enzymes of strain $\mathrm{LzC}^{\mathrm{T}}$ compared its closest relative $A$. californiensis $\mathrm{CA} 12^{\mathrm{T}}$.

\begin{tabular}{lll}
\hline & LzC2 $^{\mathrm{T}}$ & $\begin{array}{l}\text { Alienimonas californiensis } \\
\mathrm{CA}^{\mathrm{Ta}}\end{array}$ \\
\hline Carbohydrate esterases & 28 & 26 \\
Glycoside hydrolases & 48 & 56 \\
Glycosyltransferases & 57 & 77 \\
Polysaccharide lyases & 5 & 5 \\
Carbohydrate-Binding & 20 & 19 \\
Auxiliary activities & 2 & 2 \\
Unknown & 4 & 3 \\
\hline
\end{tabular}

a Genomic data from GenBank acc. no. CP036265.

Table 3

Morphological and physiological features of strain $\mathrm{LzC}^{\mathrm{T}}$ in comparison with its closest relative. Data for $A$. californiensis was taken from the species descriptions [5].

\begin{tabular}{|c|c|c|}
\hline Characteristics & $\mathrm{LzC}^{\mathrm{T}}$ & A. californiensis $\mathrm{CA} 12^{\mathrm{T}}$ \\
\hline $\begin{array}{l}\text { 16S rRNA gene sequence } \\
\text { similarity to strain } \mathrm{LzC}^{\mathrm{T}} \\
(\%)\end{array}$ & 100 & 97.0 \\
\hline Cell size $(\mu \mathrm{m})$ & $1.4 \pm 0.3 \times 1.0 \pm 0.2$ & $2.0 \pm 0.2 \times 1.5 \pm 0.3$ \\
\hline Cell shape & Spherical to ovoid & Spherical to ovoid \\
\hline Rosette formation & Observed & Not observed \\
\hline Reproduction & Budding & Budding \\
\hline $\begin{array}{l}\text { Distribution of crateriform } \\
\text { structures }\end{array}$ & Uniform & $\begin{array}{l}\text { Uniform, except for the } \\
\text { pole at which the flagellum } \\
\text { is located }\end{array}$ \\
\hline Presence of fimbriae & Yes & Yes \\
\hline Colony color & Pink & Light pink \\
\hline Source (habitat) & Chondrus crispus & Macrocystis pyrifera \\
\hline Temperature range $\left({ }^{\circ} \mathrm{C}\right)$ & $15-30$ & $10-40$ \\
\hline $\mathrm{pH}$ range & $5.5-10$ & $5.0-9.0$ \\
\hline
\end{tabular}

Table 4

Fatty acid composition of strain $\mathrm{LzC}^{\mathrm{T}}$ grown in M14 medium at $25^{\circ} \mathrm{C}$.

\begin{tabular}{|c|c|c|}
\hline Fatty acids & ECL & $\mathrm{LzC}^{\mathrm{T}}$ \\
\hline iso- $\mathrm{C}_{14: 0}$ & 13.619 & $3.7 \pm 0.1$ \\
\hline$C_{14: 0}$ & 14.000 & $0.6 \pm 0.1$ \\
\hline Summed feature 1 & 14.478 & $1.8 \pm 0.2$ \\
\hline iso- $\mathrm{C}_{15: 0}$ & 14.623 & $19.5 \pm 0.5$ \\
\hline anteiso- $\mathrm{C}_{15: 0}$ & 14.713 & $54.2 \pm 0.6$ \\
\hline iso- $\mathrm{C}_{16: 1} \mathrm{H}$ & 15.461 & $4.7 \pm 0.2$ \\
\hline iso- $\mathrm{C}_{16: 0}$ & 15.627 & $4.3 \pm 0.2$ \\
\hline Unknown 15.737 & 17.737 & $1.2 \pm 0.1$ \\
\hline Summed feature 3 & 15.822 & $1.5 \pm 0.2$ \\
\hline$C_{16: 0}$ & 16.000 & $1.1 \pm 0.1$ \\
\hline Unknown 16.090 & 16.090 & $1.3 \pm 0.1$ \\
\hline Summed feature 9 & 16.416 & $0.8 \pm 0.1$ \\
\hline anteiso- $\mathrm{C}_{17: 1} \omega 9 c$ & 15.524 & $2.4 \pm 0.1$ \\
\hline anteiso- $\mathrm{C}_{17: 0}$ & 16.723 & $1.2 \pm 0.1$ \\
\hline Summed feature 8 & 17.823 & $0.7 \pm 0.1$ \\
\hline
\end{tabular}

Results are the percentage of the total fatty acids. \pm SD, the results are the mean plus the standard deviation of two to four analyses; values for fatty acids present at less than $0.5 \%$ are not shown; ECL, equivalent chain length. A summed feature represents groups of two or three fatty acids that could not be separated by GLC with the MIDI System. Summed feature 1 comprises iso-C15:0 $\mathrm{H}$ and/or C13:0 3$\mathrm{OH}$; Summed feature 3 comprises C16:1 w7c and/or C16:1 w6c and/or iso-C15:0 2$\mathrm{OH}$; Summed feature 9 comprises iso-C17:1 w9c and/or C16:0 10-methyl; Summed feature 8 comprises $\mathrm{C} 18: 1 \mathrm{w} 7 \mathrm{c}$ and/or C18:1 w6c.

ilar tubular neck-like structure has been reported before [27,31]. The closely related strain $A$. californiensis $\mathrm{CA} 12^{\mathrm{T}}$ was described to reproduce by unique consecutive polar budding, without completing a characteristic planctomycetal lifestyle switch [5]. However, this was not observed in our strain. The presence of a large amount of fibers as reported in A. californiensis was also not observed in $\mathrm{LzC}_{2}^{\mathrm{T}}$. On the other hand, the previously referred tubular structure formed during the budding of our isolate was not detected in $\mathrm{CA} 12^{\mathrm{T}}$. Although similar in size and shape, it is clear that its bud-
Table 5

Description of Alienimonas chondri sp. nov.

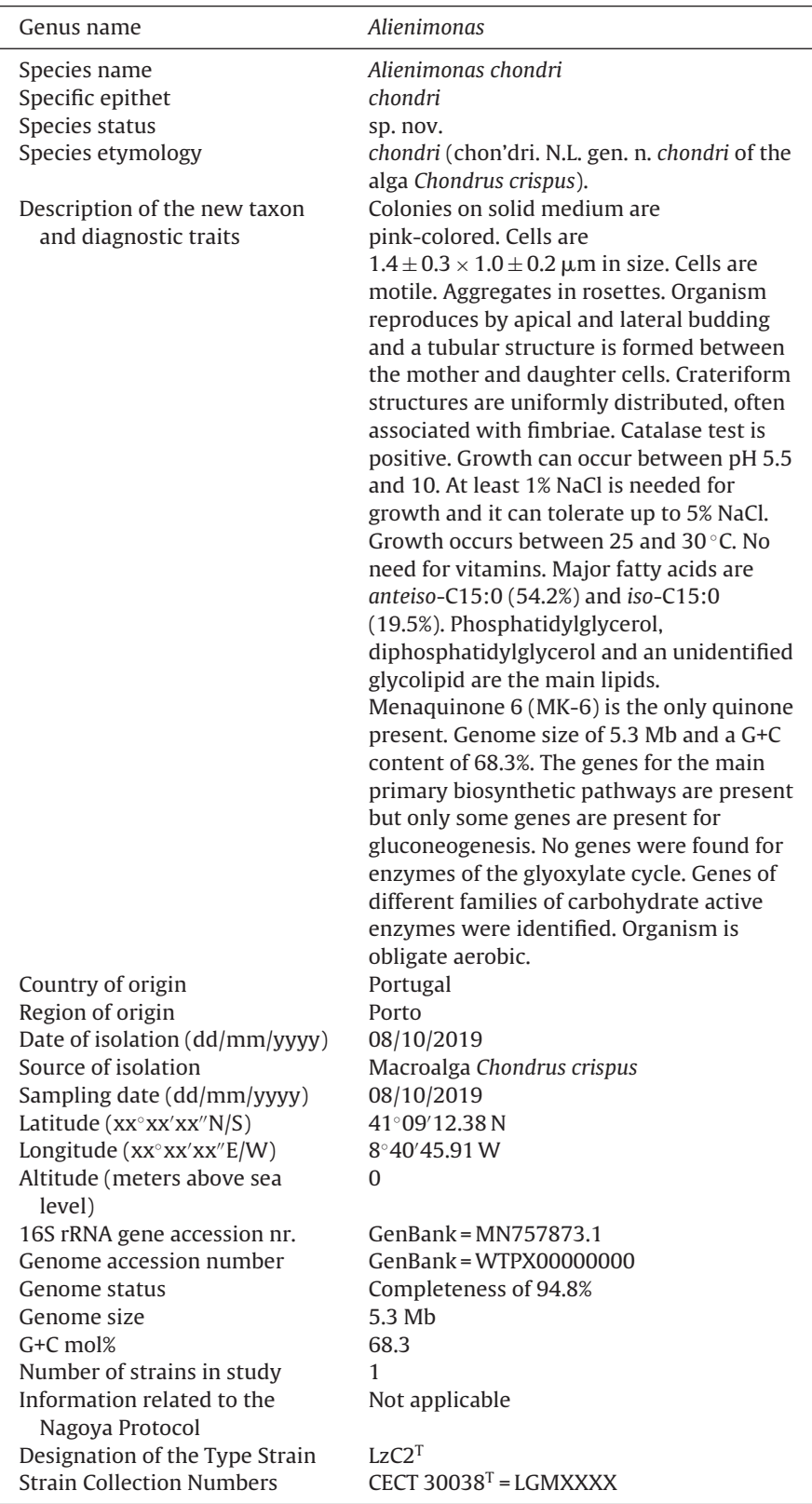

ding process and morphology distinguish our strain from its peers $[5,30,45]$.

Strain $\mathrm{LzC}^{\mathrm{T}}$ required salt to grow (at least $1 \%(\mathrm{w} / \mathrm{v}) \mathrm{NaCl}$ ) and could also tolerate concentrations of up to $5 \% \mathrm{NaCl}$. Growth occurred from 15 to $30^{\circ} \mathrm{C}$, in a pH range from 5.5 to 10 and did not require vitamins. $\mathrm{LzC} 2^{\mathrm{T}}$ is catalase positive. $\mathrm{LzC} 2^{\mathrm{T}}$ major fatty acids are anteiso-C15:0 (54.2\%) and iso-C15:0 (19.5\%) (Table 4). The major polar lipids of $\mathrm{LzC}^{\mathrm{T}}$ are phosphatidylglycerol, diphosphatidylglycerol one unidentified phospholipid and one unidentified glycolipid (Supplementary Fig. 1). The only respiratory quinone of strain $\mathrm{LzC}^{\mathrm{T}}$ is menaquinone 6 (MK-6). This strain is an obligate aerobic, as it did not grow on anaerobic conditions.

\section{Conclusion}

Both phenotypic and genotypic characteristics support that the novel isolate represents a novel species within the genus Alienimonas. Therefore, we propose the name Alienimonas chondri sp. 
nov., with $\mathrm{LzC}^{\mathrm{T}}$ being the type strain. The formal description of the species is shown in Table 5 .

\section{Ethical statement}

This article does not contain any studies with animals performed by any of the authors.

\section{Funding}

This research was partially supported by the Strategic Funding UID/Multi/04423/2019 through national funds provided by FCT - Foundation for Science and Technology and European Regional Development Fund (ERDF), in the framework of the program PT2020, by the Structured Program of R\&D\&I INNOVMAR-Innovation and Sustainability in the Management and Exploitation of Marine Resources, reference Norte-01-0145-FEDER-NORTE-01-0145-FEDER-000035 (grant NOVELMAR/BI/2018-064) and by Fundação para a Ciência e Tecnologia (Ph.D. grant SFRH/BD/145577/2019).

\section{Author contributions}

The design of the experiments was done by IV and OML. The performing of the scientific work by IV, LA, SW, NK, ALC, and OML. Manuscript writing by IV, LA, SW, NK, MSC, ALC, CJ and OML.

\section{Conflict of interest}

The authors declare that they have no conflict of interest.

\section{Appendix A. Supplementary data}

Supplementary material related to this article can be found, in the online version, at https://doi.org/10.1016/j.syapm.2020. 126083.

\section{References}

[1] Bankevich, A., Nurk, S., Antipov, D., Gurevich, A.A., Dvorkin, M., Kulikov, A.S., Lesin, V.M., Nikolenko, S.I., Pham, S., Prjibelski, A.D., Pyshkin, A.V., Sirotkin, A.V., Vyahhi, N., Tesler, G., Alekseyev, M.A., Pevzner, P.A. (2012) SPAdes: a new genome assembly algorithm and its applications to single-cell sequencing. J. Comput. Biol. 19, 455-477, http://dx.doi.org/10.1089/cmb.2012.0021.

[2] Bengtsson, M., Øvreås, L. (2010) Planctomycetes dominate biofilms on surfaces of the kelp Laminaria hyperborea. BMC Microbiol. 10, 261, http://dx.doi.org/10. 1186/1471-2180-10-261.

[3] Blin, K., Shaw, S., Steinke, K., Villebro, R., Ziemert, N., Lee, S.Y., Medema, M.H., Weber, T. (2019) antiSMASH 5.0: updates to the secondary metabolite genome mining pipeline. Nucleic Acids Res. 47, W81-W87, http://dx.doi.org/10.1093/ nar/gkz310.

[4] Boedeker, C., Schuler, M., Reintjes, G., Jeske, O., van Teeseling, M.C., Jogler, M., Rast, P., Borchert, D., Devos, D.P., Kucklick, M., Schaffer, M., Kolter, R., van Niftrik, L., Engelmann, S., Amann, R., Rohde, M., Engelhardt, H., Jogler, C. (2017) Determining the bacterial cell biology of Planctomycetes. Nat. Commun. 8, 14853, http://dx.doi.org/10.1038/ncomms14853.

[5] Boersma, A.S., Kallscheuer, N., Wiegand, S., Rast, P., Peeters, S.H., Mesman, R.J., Heuer, A., Boedeker, C., Jetten, M.S.M., Rohde, M., Jogler, M., Jogler, C. (2019) Alienimonas californiensis gen. nov. sp. nov., a novel Planctomycete isolated from the kelp forest in Monterey Bay. Antonie Van Leeuwenhoek, http://dx. doi.org/10.1007/s10482-019-01367-4.

[6] Boetzer, M., Henkel, C.V., Jansen, H.J., Butler, D., Pirovano, W. (2011) Scaffolding pre-assembled contigs using SSPACE. Bioinformatics 27, 578-579, http://dx. doi.org/10.1093/bioinformatics/btq683.

[7] Bolger, A.M., Lohse, M., Usadel, B. (2014) Trimmomatic: a flexible trimmer for Illumina sequence data. Bioinformatics 30, 2114-2120, http://dx.doi.org/10. 1093/bioinformatics/btu170.

[8] Bondoso, J., Albuquerque, L., Lobo-da-Cunha, A., da Costa, M.S., Harder, J., Lage, O.M. (2014) Rhodopirellula lusitana sp. nov. and Rhodopirellula rubra sp. nov., isolated from the surface of macroalgae. Syst. Appl. Microbiol. 37, 157-164, http://dx.doi.org/10.1016/j.syapm.2013.11.004.

[9] Bondoso, J., Albuquerque, L., Nobre, M.F., Lobo-da-Cunha, A., da Costa, M.S., Lage, O.M. (2011) Aquisphaera giovannonii gen. nov., sp. nov., a planctomycete isolated from a freshwater aquarium. Int. J. Syst. Evol. Microbiol. 61, 2844-2850, http://dx.doi.org/10.1099/ijs.0.027474-0.

[10] Bondoso, J., Albuquerque, L., Nobre, M.F., Lobo-da-Cunha, A., da Costa, M.S. Lage, O.M.(2015) Roseimaritima ulvae gen. nov., sp. nov. and Rubripirellula obstinata gen. nov., sp. nov. two novel planctomycetes isolated from the epiphytic community of macroalgae. Syst. Appl. Microbiol. 38, 8-15, http://dx.doi.org/ 10.1016/j.syapm.2014.10.004.

[11] Bondoso, J., Harder, J., Lage, O.M. (2013) rpoB gene as a novel molecular marker to infer phylogeny in Planctomycetales. Antonie Van Leeuwenhoek 104, 477-488, http://dx.doi.org/10.1007/s10482-013-9980-7.

[12] Calisto, R., Sæbø, E., Storesund, J., Øvreås, L., Herfindal, L., Lage, O. (2019) Anticancer activity in Planctomycetes. Front. Mar. Sci., 5, http://dx.doi.org/10.3389/ fmars.2018.00499.

[13] Castresana, J. (2000) Selection of conserved blocks from multiple alignments for their use in phylogenetic analysis. Mol. Biol. Evol. 17, 540-552, http://dx. doi.org/10.1093/oxfordjournals.molbev.a026334.

[14] da Costa, M.S., Albuquerque, L., Nobre, M.F., Wait, R. (2011) The identification of polar lipids in prokaryotes. In: Rainey, F. Oren, A. (Eds.), Methods in Microbiol, vol. 38, Academic Press, pp. 165-181 (Chapter 7)

[15] da Costa, M.S., Albuquerque, L., Nobre, M.F., Wait, R. (2011) The identification of fatty acids in bacteria. In: Rainey, F., Oren, A. (Eds.), Methods in Microbiol, vol. 38, Academic Press, pp. 183-196 (Chapter 8)

[16] da Costa, M.S., Albuquerque, L., Nobre, M.F., Wait, R. (2011) The extraction and identification of respiratory lipoquinones of prokaryotes and their use in taxonomy. In: Rainey, F., Oren, A. (Eds.), Methods in Microbiol, vol. 38, Academic Press, pp. 197-206 (Chapter 9)

[17] Dedysh, S.N., Kulichevskaya, I.S., Beletsky, A.V., Ivanova, A.A., Rijpstra, W.I.C., Damste, J.S.S., Mardanov, A.V., Ravin, N.V. (2020) Lacipirellula parvula gen. nov. sp. nov., representing a lineage of planctomycetes widespread in low-oxygen habitats, description of the family Lacipirellulaceae fam. nov. and proposal of the orders Pirellulales ord. nov., Gemmatales ord. nov. and Isosphaerales ord. nov. Syst. Appl. Microbiol. 43,126050, http://dx.doi.org/10.1016/j.syapm.2019. 126050.

[18] Donadio, S., Monciardini, P., Sosio, M. (2007) Polyketide synthases and nonribosomal peptide synthetases: the emerging view from bacterial genomics. Nat. Prod. Rep. 24, 1073-1109, http://dx.doi.org/10.1039/b514050c.

[19] Edgar, R.C. (2004) MUSCLE: multiple sequence alignment with high accuracy and high throughput. Nucleic Acids Res. 32, 1792-1797, http://dx.doi.org/10. 1093/nar/gkh340.

[20] Faria, M., Bordin, N., Kizina, J., Harder, J., Devos, D., Lage, O.M. (2018) Planctomycetes attached to algal surfaces: Insight into their genomes. Genomics 110 , 231-238, http://dx.doi.org/10.1016/j.ygeno.2017.10.007.

[21] Graca, A.P., Calisto, R., Lage, O.M. (2016) Planctomycetes as novel source of bioactive molecules. Front. Microbiol. 7, 1241, http://dx.doi.org/10.3389/fmicb. 2016.01241.

[22] Gurevich, A., Saveliev, V., Vyahhi, N., Tesler, G. (2013) QUAST: quality assessment tool for genome assemblies. Bioinformatics 29, 1072-1075, http://dx.doi. org/10.1093/bioinformatics/btt086.

[23] Jeske, O., Jogler, M., Petersen, J., Sikorski, J., Jogler, C. (2013) From genome mining to phenotypic microarrays: Planctomycetes as source for novel bioactive molecules. Antonie Van Leeuwenhoek 104, 551-567, http://dx.doi.org/10. 1007/s10482-013-0007-1.

[24] Jeske, O., Surup, F., Ketteniss, M., Rast, P., Forster, B., Jogler, M., Wink, J., Jogler, C. (2016) Developing techniques for the utilization of Planctomycetes as producers of bioactive molecules. Front. Microbiol. 7, 1242, http://dx.doi.org/10. 3389/fmicb.2016.01242.

[25] Kallscheuer, N., Wiegand, S., Peeters, S.H., Jogler, M., Boedeker, C., Heuer, A Rast, P., Jetten, M.S.M., Rohde, M., Jogler, C. (2019) Description of three bacterial strains belonging to the new genus Novipirellula gen. nov., reclassificiation of Rhodopirellula rosea and Rhodopirellula caenicola and readjustment of the genus threshold of the phylogenetic marker rpoB for Planctomycetaceae. Antonie Van Leeuwenhoek, http://dx.doi.org/10.1007/s10482-019-01374-5.

[26] Kim, M., Oh, H.S., Park, S.C., Chun, J. (2014) Towards a taxonomic coherence between average nucleotide identity and 16S rRNA gene sequence similarity for species demarcation of prokaryotes. Int. J. Syst. Evol. Microbiol. 64, 346-351, http://dx.doi.org/10.1099/ijs.0.059774-0.

[27] Kohn, T., Heuer, A., Jogler, M., Vollmers, J., Boedeker, C., Bunk, B, Rast, P. Borchert, D., Glöckner, I., Freese, H.M., Klenk, H.-P., Overmann, J., Kaster, A.K., Rohde, M., Wiegand, S., Jogler, C. (2016) Fuerstia marisgermanicae gen. nov., sp. nov., an Unusual Member of the Phylum Planctomycetes from the German Wadden Sea. Front. Microbiol. 7, 2079, http://dx.doi.org/10.3389/fmicb.2016. 02079

[28] Kohn, T., Heuer, A., Jogler, M., Vollmers, J., Boedeker, C., Bunk, B., Rast, P. Borchert, D., Glockner, I., Freese, H.M., Klenk, H.P., Overmann, J., Kaster, A.K., Rohde, M., Wiegand, S., Jogler, C. (2019) Corrigendum: Fuerstia marisgermanicae gen. nov., sp. nov., an unusual member of the phylum Planctomycetes from the German Wadden Sea. Front Microbiol. 10, 1029, http://dx.doi.org/10.3389/ fmicb.2019.01029.

[29] Konstantinidis, K.T., Tiedje, J.M. (2005) Towards a genome-based taxonomy for prokaryotes. J. Bacteriol. 187, 6258-6264, http://dx.doi.org/10.1128/JB.187.18. 6258-6264.2005.

[30] Kulichevskaya, I.S., Ivanova, A.A., Detkova, E.N., Rijpstra, W.I., Sinninghe Damste, J.S., Dedysh, S.N. (2015) Planctomicrobium piriforme gen. nov., sp. nov., a stalked planctomycete from a littoral wetland of a boreal lake. Int. J. Syst. Evol. Microbiol. 65, 1659-1665, http://dx.doi.org/10.1099/ijs.0.000154. 
[31] Lage, O.M. (2013) Characterization of a planctomycete associated with the marine dinoflagellate Prorocentrum micans Her. Antonie Van Leeuwenhoek 104, 499-508, http://dx.doi.org/10.1007/s10482-013-9991-4.

[32] Lage, O.M., Albuquerque, L., Lobo-da Cunha, A., da Costa, M.S. (2017) Mariniblastus fucicola gen. nov., sp. nov. a novel planctomycete associated with macroalgae. Int. J. Syst. Evol. Microbiol. 67, 1571-1576, http://dx.doi.org/10. 1099/ijsem.0.001760.

[33] Lage, O.M., Bondoso, J. (2011) Planctomycetes diversity associated with macroalgae. FEMS Microbiol. Ecol. 78, 366-375, http://dx.doi.org/10.1111/j. 1574-6941.2011.01168.x.

[34] Lage, O.M., Bondoso, J., Lobo-da-Cunha, A. (2013) Insights into the ultrastructural morphology of novel Planctomycetes. Antonie Van Leeuwenhoek 104, 467-476, http://dx.doi.org/10.1007/s10482-013-9969-2.

[35] Lage, O.M., van Niftrik, L., Jogler, C., Devos, D.P. (2019) Planctomycetes. In: Schmidt, T.M. (Ed.), Encyclopedia of Microbiology, 4th ed., Academic Press, Oxford, pp. 614-626.

[36] Lechner, M., Findeiß, S., Steiner, L., Marz, M., Stadler, P.F., Prohaska, S.J. (2011) Proteinortho: detection of (co-)orthologs in large-scale analysis. BMC Bioinformatics 12, 124, http://dx.doi.org/10.1186/1471-2105-12-124.

[37] Lee, I., Ouk Kim, Y., Park, S.C., Chun, J. (2016) OrthoANI: an improved algorithm and software for calculating average nucleotide identity. Int. J. Syst. Evol. Microbiol. 66, 1100-1103, http://dx.doi.org/10.1099/ijsem.0.000760.

[38] Lombard, V., Golaconda Ramulu, H., Drula, E., Coutinho, P.M., Henrissat, B. (2014) The carbohydrate-active enzymes database (CAZy) in 2013. Nucleic Acids Res. 42, D490-D495, http://dx.doi.org/10.1093/nar/gkt1178.

[39] Magoc, T., Salzberg, S.L. (2011) FLASH: fast length adjustment of short reads to improve genome assemblies. Bioinformatics 27, 2957-2963, http://dx.doi.org/ 10.1093/bioinformatics/btr507.

[40] Mitchell, A.L., Attwood, T.K., Babbitt, P.C., Blum, M., Bork, P., Bridge, A., Brown, S.D., Chang, H.Y., El-Gebali, S., Fraser, M.I., Gough, J., Haft, D.R., Huang, H., Letunic, I., Lopez, R., Luciani, A., Madeira, F., Marchler-Bauer, A., Mi, H., Natale, D.A., Necci, M., Nuka, G., Orengo, C., Pandurangan, A.P., Paysan-Lafosse, T. Pesseat, S., Potter, S.C., Qureshi, M.A., Rawlings, N.D., Redaschi, N., Richardson, L.J., Rivoire, C., Salazar, G.A., Sangrador-Vegas, A., Sigrist, C.J.A., Sillitoe, I., Sutton, G.G., Thanki, N., Thomas, P.D., Tosatto, S.C.E., Yong, S.Y., Finn, R.D. (2019) InterPro in 2019: improving coverage, classification and access to protein sequence annotations. Nucleic Acids Res. 47, D351-D360, http://dx.doi.org/10.1093/nar/ gky1100.

[41] Parks, D.H., Imelfort, M., Skennerton, C.T., Hugenholtz, P., Tyson, G.W. (2015) CheckM: assessing the quality of microbial genomes recovered from isolates, single cells, and metagenomes. Genome Res. 25, 1043-1055, http://dx.doi.org/ 10.1101/gr.186072.114.

[42] Pruesse, E., Peplies, J., Glockner, F.O. (2012) SINA: accurate high-throughput multiple sequence alignment of ribosomal RNA genes. Bioinformatics 28 , 1823-1829, http://dx.doi.org/10.1093/bioinformatics/bts252.

[43] Qin, Q.L., Xie, B.B., Zhang, X.Y., Chen, X.L., Zhou, B.C., Zhou, J., Oren, A., Zhang Y.Z. (2014) A proposed genus boundary for the prokaryotes based on genomic insights. J. Bacteriol. 196, 2210-2215, http://dx.doi.org/10.1128/JB. 01688-14.
[44] Rodriguez-R, L.M., Konstantinidis, K.T. (2016) The enveomics collection: a tool box for specialized analyses of microbial genomes and metagenomes. Peer] Preprints 4, e1900v1901, http://dx.doi.org/10.7287/peerj.preprints.1900v1.

[45] Schlesner, H. (1989) Planctomyces brasiliensis sp. nov., a halotolerant bacterium from a salt pit. Syst. Appl. Microbiol. 12, 159-161, http://dx.doi.org/10.1016/ S0723-2020(89)80008-6.

[46] Schmieder, R., Edwards, R. (2011) Quality control and preprocessing of metagenomic datasets. Bioinformatics 27, 863-864, http://dx.doi.org/10.1093/ bioinformatics/btr026.

[47] Seemann, T. (2014) Prokka: rapid prokaryotic genome annotation. Bioinformatics 30, 2068-2069, http://dx.doi.org/10.1093/bioinformatics/btu153.

[48] Sievers, F., Wilm, A., Dineen, D., Gibson, T.J., Karplus, K., Li, W., Lopez, R., McWilliam, H., Remmert, M., Soding, J., Thompson, J.D., Higgins, D.G. (2011) Fast, scalable generation of high-quality protein multiple sequence alignments using Clustal Omega. Mol. Syst. Biol. 7, 539, http://dx.doi.org/10.1038/msb. 2011.75.

[49] Stamatakis, A. (2014) RAxML version 8: a tool for phylogenetic analysis and post-analysis of large phylogenies. Bioinformatics 30, 1312-1313, http://dx. doi.org/10.1093/bioinformatics/btu033.

[50] UniProt, C. (2019) UniProt: a worldwide hub of protein knowledge. Nucleic Acids Res. 47, D506-D515, http://dx.doi.org/10.1093/nar/gky1049.

[51] Wagner, M., Horn, M. (2006) The Planctomycetes, Verrucomicrobia, Chlamydiae and sister phyla comprise a superphylum with biotechnological and medical relevance. Curr. Opin Biotechnol. 17, 241-249, http://dx.doi.org/10. 1016/j.copbio.2006.05.005.

[52] Wiegand, S., Jogler, M., Boedeker, C., Pinto, D., Vollmers, J., Rivas-Marin, E., Kohn, T., Peeters, S.H., Heuer, A., Rast, P., Oberbeckmann, S., Bunk, B., Jeske, O., Meyerdierks, A., Storesund, J.E., Kallscheuer, N., Lucker, S., Lage, O.M., Pohl, T., Merkel, B.J., Hornburger, P., Muller, R.W., Brummer, F., Labrenz, M., Spormann, A.M., Op den Camp, H.J.M., Overmann, J., Amann, R., Jetten, M.S.M., Mascher, T., Medema, M.H., Devos, D.P., Kaster, A.K., Ovreas, L., Rohde, M., Galperin, M.Y. Jogler, C. (2020) Cultivation and functional characterization of 79 planctomycetes uncovers their unique biology. Nat. Microbiol. 5, 126-140, http:/| dx.doi.org/10.1038/s41564-019-0588-1.

[53] Wiegand, S., Jogler, M., Jogler, C. (2018) On the maverick Planctomycetes. FEMS Microbiol. Rev. 42, 739-760, http://dx.doi.org/10.1093/femsre/fuy029.

[54] Wingett, S.W., Andrews, S. (2018) FastQ Screen: a tool for multi-genome mapping and quality control. F1000Res 7, 1338, http://dx.doi.org/10.12688 f1000research.15931.2.

[55] Yarza, P., Yilmaz, P., Pruesse, E., Glockner, F.O., Ludwig, W., Schleifer, K.H., Whitman, W.B., Euzeby, J., Amann, R., Rossello-Mora, R. (2014) Uniting the classification of cultured and uncultured bacteria and archaea using 16S rRNA gene sequences. Nat. Rev. Microbiol. 12, 635-645, http://dx.doi.org/10.1038/ nrmicro3330.

[56] Zhang, H., Yohe, T., Huang, L., Entwistle, S., Wu, P., Yang, Z., Busk, P.K., Xu, Y., Yin, Y. (2018) dbCAN2: a meta server for automated carbohydrate-active enzyme annotation. Nucleic Acids Res. 46, W95-W101, http://dx.doi.org/10.1093/nar/ gky418. 